Violaxanthin-Moleküle umgesetzt, was 110 mehr sind als beim Ausgangsstamm und $64 \%$ der Anfangsmenge entspricht. Gleichzeitig steigt der relative AntheraxanthinGehalt von 0 auf 72 und der Zeaxanthingehalt von 1 auf 123 .

Der erhöhte Violaxanthin-Gehalt der gegenüber dem Ausgangsstamm ps etwas lichtempfindlicheren Mutante $p g-113$ könnte durch eine adaptive Verstärkung des Schutzmechanismus gegen Photo-Oxydation oder aber durch einen etwas geringeren Chlorophyll-Gehalt in der Mutante erklärt werden. Es ist auffallend, dass der Zeaxanthin-Spiegel nach Erreichen des Gleichgewichtes in beiden Stämmen fast gleich hoch ist. Entsprechend der Molsumme der drei Pigmente hat die Mutante dafür mehr Antheraxanthin in Gleichgewicht. Durch den grösseren Umsatz an Violaxanthin in $p g-113$ verbraucht die Mutante möglicherweise auch mehr Reduktionsmittel, Ascorbat und NADPH, als der Ausgangsstamm.

pg-101: Auffallend ist der extrem hohe relative Violaxanthin-Gehalt nach der Dunkel-Inkubation; er beträgt 870 pmol pro nmol Chlorophyll $a$, d.h. 3,2mal mehr als im Ausgangsstamm (Fig. 1 und 2). Nach Belichtung sinkt er nur auf 497. Dieser gegenüber den Stämmen ps und pg-113 3,8mal höhere Rest-Violaxanthin-Gehaltkönnte gemäss der einleitend geschilderten Hypothese auf einen grossen Pool festgebundenen Pigmentes hindeuten. Die umgewandelte, relative Menge an Violaxanthin beträgt 373 pmol pro nmol Chlorophyll $a$ also $43 \%$ der Ausgangsmenge. Das sind 1,4mal mehr als in $p g-113$ und $2,5 \mathrm{mal}$ als in $p s$. Parallel steigen die relativen Gehalte an Taraxanthin (?) von 81 auf 157, und von Lutein (?) von 40 auf 275. Auch hier vermuten wir also einen höheren Verbrauch an Reduktionsmitteln.

Die hier untersuchten Mutanten von Chlamydomonas reinhardii zeichnen sich primär durch ihr unterschiedliches Pigmentmuster und somit ihre gestörten Pigment-Protein-Komplexe aus. Obwohl sie vom selben Ausgangsstamm herstammen, zeigen sie zudem einen ganz anderen Verlauf des Xanthophyll-Zyklus. Möglicherweise erlaubt ihre weitere Untersuchung die Bedeutung der einzelnen Pigmente und des Xanthophyll-Zyklus in grünen Pflanzen etwas zu erhellen.

Wir danken Frau Dr. Siefermann-Harms, Karlsruhe für Beratung und Hilfestellung bei der Pigmentanalyse. Die Arbeit wurde teilweise durch den Schn'eiz. Nationalfonds unterstützt.
CHIMIA 45 (1991) Nr.1/2 (Jilluair/Fehruar)

Eingegangen am 11. Dezember 1990

[1] R.J.Cogdell, H.A. Frank, Binchim. Biophy's. Acta 1987, $895,63$.

[2] D. Siefermann-Harms, Physiol. Plant 1987, 69. 561 .

[3] N.I. Krinsky, Pure Appl. Chenı. 1979, 51, 649.

[4] B. Demmig-Adams, Nanuru'issenschafren 1989. $76,262$.

[5] D. Siefermann-Harms, in 'Lipids and lipid polymers in higher plants', Eds. M. Tevini und H.K. Lichtenthaler, Springer-Verlag, Berlin, 1977, S. 218.

[6] D.I. Sapozhnikov, T.A. Krasovskaya, A.N. Mayeskaya, Dokl. Akad. Nauk. USSR 1957,113. 465.

17] A. Hager, Ber. Disch. Bot. Ges. 1975, 88, 27.

[8] D. Siefermann-Harms, Photochem. Photohiol. $1984,40,507$.

[9] D. Siefermann, in 'Proc. 2nd Int. Congr. Photosynth.', Eds. G. Forti, M. Avron und A. Melandri, W. Junk Publ., 1972, S. 629

[10] H.P. Michel, M. Tellenbach, A. Boschenti, Biochim. Biophys. Acra 1983, 725, 417; M. Tellenbach, Dissertation, Universität Bern, 1984.

[11] A. S. Chunayev, N. G. Averina, A. Boschetti, E. M. Chekunova, N. V. Shalygo, in 'The topics of interaction of photosynthesis and respiration', Ed.V.L. Voznesensky, Tomsk University Press, 1988, S. 199; M. Tellenbach, Dissertation Bern, 1984.

[12] A. Boschetti, E. Sauton-Heiniger, J.C. Schaffner, W. Eichenberger, Physiol. Plant. 1978, 44. 134.
Chimia 45 (1991) 43-45

(C) Schweiz. Chemiker-Verband; ISSN 0009-4293

\section{Gas-phase Sequencing of Photoimmobilized Peptides}

\author{
Vibhuti Klingler-Dabral ${ }^{2}$ ), André Collioud ${ }^{1}$ ), Johann Schaller ${ }^{1}$ ), Franz Herbst ${ }^{2}$ ), \\ Wolf-Georg Forssmann ${ }^{2}$ ), and Hans Sigrist ${ }^{1}$ )*
}

Abstract. Aminopropylated glass-fiber discs were derivatized with the photosensitive reagents 3-(trifluoromethyl)-3-[m-(isothiocyano)phenyl]diazirine and $p$-azidophenyl isothiocyanate, respectively. Photolabel-derivatized solid supports were photoactivated in the presence of a hexapeptide. Gas-phase sequence analysis of washed fiber discs yielded end-to-end sequences with photoactivated disks only, indicating efficient photo-immobilization of the applied peptide. The quantity of amino acid released with each Edman-degradation cycle conferred with the established philicity of amino-acid side chains for photogenerated carbenes. The procedure provides a hitherto unexplored way to immobilize biomolecules (polypeptides) through statistically occurring carbene or nitrene insertions.

\section{Introduction}

Adsorption or covalent immobilization of polypeptides to solid supports are crucial steps in bio-analytical procedures including electrophoretic transfer of proteins from polyacrylamide gels to solid supports by electroblotting and immobilization of polypeptides for solid-phase and gas-phase sequence analysis. The efficiency of the methods mentioned depends on the protein-bin- ding capacity of the supporting material. To date, chemically inert supports are either pretreated or modified by various means to achieve improved polypeptide retention. For sequencing purposes, glass fibers are coated with polybrene, a quaternary ammonium polybase, or modified with positively of ionic forces to retain the adsorbed protein [1][2]. Covalently modified glass fibers, derived with bifunctional reagents, provide charged silanes. Both procedures make use means for group-specific protein binding [3][4]. Hydrophobic and electrostatic forces are involved in polypeptide retention on siliconized glass fiber [5] and polyvinylidenedifluoride (PVDF) membranes [6].

This study reports on the preparation and characterization of photoactivable supports, which carry monomolecular layers of carbene- or nitrene-generating photoreagents. Photo-activation of photolabel-derived supports in the presence of a hexapeptide leads to covalent polypeptide immobilization by carbene/nitrene insertion. Evidence is presented that photocoupled peptides can be sequenced by $E d m a n$-degradation-based gasphase microsequencing.

\section{Experimental}

Photoactivable Glass Fibers: Preparation and Loading

The bifunctional photoreagents 3-(trifluoromethyl)3-[m-(isothiocyano)phenyl]diazirine (TRIMID) and $p$ azidophenyl isothiocyanate (API) were synthesized as described in [7][8]. GF/C glass fiber sheets (Whatmam) were aminopropylated according to Aebersold et al. [2] yielding 14 nmol of $\mathrm{NH}$ groups per mg glass fiber. Dried aminopropylated glass-fiber sheets were cut into dises of $1.2 \mathrm{~cm}$ in diameter.

\footnotetext{
*Correspondence: PD Dr. Hans Sigrist

1) Institut für Biochemie

Universität Bern

Freiestrasse 3, CH-3012 Bern

2) Niedersächsisches Institut für Peptidforschung im Medical Park

Feodor-Lynen-Strasse 5, D-3000 Hannover 61
} 
Violaxanthin-Moleküle umgesetzt, was 110 mehr sind als beim Ausgangsstamm und $64 \%$ der Anfangsmenge entspricht. Gleichzeitig steigt der relative AntheraxanthinGehalt von 0 auf 72 und der Zeaxanthingehalt von 1 auf 123 .

Der erhöhte Violaxanthin-Gehalt der gegenüber dem Ausgangsstamm ps etwas lichtempfindlicheren Mutante $p g-113$ könnte durch eine adaptive Verstärkung des Schutzmechanismus gegen Photo-Oxydation oder aber durch einen etwas geringeren Chlorophyll-Gehalt in der Mutante erklärt werden. Es ist auffallend, dass der Zeaxanthin-Spiegel nach Erreichen des Gleichgewichtes in beiden Stämmen fast gleich hoch ist. Entsprechend der Molsumme der drei Pigmente hat die Mutante dafür mehr Antheraxanthin in Gleichgewicht. Durch den grösseren Umsatz an Violaxanthin in $p g-113$ verbraucht die Mutante möglicherweise auch mehr Reduktionsmittel, Ascorbat und NADPH, als der Ausgangsstamm.

pg-101: Auffallend ist der extrem hohe relative Violaxanthin-Gehalt nach der Dunkel-Inkubation; er beträgt 870 pmol pro nmol Chlorophyll $a$, d.h. 3,2mal mehr als im Ausgangsstamm (Fig. 1 und 2). Nach Belichtung sinkt er nur auf 497. Dieser gegenüber den Stämmen ps und pg-113 3,8mal höhere Rest-Violaxanthin-Gehaltkönnte gemäss der einleitend geschilderten Hypothese auf einen grossen Pool festgebundenen Pigmentes hindeuten. Die umgewandelte, relative Menge an Violaxanthin beträgt 373 pmol pro nmol Chlorophyll $a$ also $43 \%$ der Ausgangsmenge. Das sind 1,4mal mehr als in $p g-113$ und $2,5 \mathrm{mal}$ als in $p s$. Parallel steigen die relativen Gehalte an Taraxanthin (?) von 81 auf 157, und von Lutein (?) von 40 auf 275. Auch hier vermuten wir also einen höheren Verbrauch an Reduktionsmitteln.

Die hier untersuchten Mutanten von Chlamydomonas reinhardii zeichnen sich primär durch ihr unterschiedliches Pigmentmuster und somit ihre gestörten Pigment-Protein-Komplexe aus. Obwohl sie vom selben Ausgangsstamm herstammen, zeigen sie zudem einen ganz anderen Verlauf des Xanthophyll-Zyklus. Möglicherweise erlaubt ihre weitere Untersuchung die Bedeutung der einzelnen Pigmente und des Xanthophyll-Zyklus in grünen Pflanzen etwas zu erhellen.

Wir danken Frau Dr. Siefermann-Harms, Karlsruhe für Beratung und Hilfestellung bei der Pigmentanalyse. Die Arbeit wurde teilweise durch den Schn'eiz. Nationalfonds unterstützt.
CHIMIA 45 (1991) Nr.1/2 (Jilluair/Fehruar)

Eingegangen am 11. Dezember 1990

[1] R.J.Cogdell, H.A. Frank, Binchim. Biophy's. Acta 1987, $895,63$.

[2] D. Siefermann-Harms, Physiol. Plant 1987, 69. 561 .

[3] N.I. Krinsky, Pure Appl. Chenı. 1979, 51, 649.

[4] B. Demmig-Adams, Nanuru'issenschafren 1989. $76,262$.

[5] D. Siefermann-Harms, in 'Lipids and lipid polymers in higher plants', Eds. M. Tevini und H.K. Lichtenthaler, Springer-Verlag, Berlin, 1977, S. 218.

[6] D.I. Sapozhnikov, T.A. Krasovskaya, A.N. Mayeskaya, Dokl. Akad. Nauk. USSR 1957,113. 465.

17] A. Hager, Ber. Disch. Bot. Ges. 1975, 88, 27.

[8] D. Siefermann-Harms, Photochem. Photohiol. $1984,40,507$.

[9] D. Siefermann, in 'Proc. 2nd Int. Congr. Photosynth.', Eds. G. Forti, M. Avron und A. Melandri, W. Junk Publ., 1972, S. 629

[10] H.P. Michel, M. Tellenbach, A. Boschenti, Biochim. Biophys. Acra 1983, 725, 417; M. Tellenbach, Dissertation, Universität Bern, 1984.

[11] A. S. Chunayev, N. G. Averina, A. Boschetti, E. M. Chekunova, N. V. Shalygo, in 'The topics of interaction of photosynthesis and respiration', Ed.V.L. Voznesensky, Tomsk University Press, 1988, S. 199; M. Tellenbach, Dissertation Bern, 1984.

[12] A. Boschetti, E. Sauton-Heiniger, J.C. Schaffner, W. Eichenberger, Physiol. Plant. 1978, 44. 134.
Chimia 45 (1991) 43-45

(C) Schweiz. Chemiker-Verband; ISSN 0009-4293

\section{Gas-phase Sequencing of Photoimmobilized Peptides}

\author{
Vibhuti Klingler-Dabral ${ }^{2}$ ), André Collioud ${ }^{1}$ ), Johann Schaller ${ }^{1}$ ), Franz Herbst ${ }^{2}$ ), \\ Wolf-Georg Forssmann ${ }^{2}$ ), and Hans Sigrist ${ }^{1}$ )*
}

Abstract. Aminopropylated glass-fiber discs were derivatized with the photosensitive reagents 3-(trifluoromethyl)-3-[m-(isothiocyano)phenyl]diazirine and $p$-azidophenyl isothiocyanate, respectively. Photolabel-derivatized solid supports were photoactivated in the presence of a hexapeptide. Gas-phase sequence analysis of washed fiber discs yielded end-to-end sequences with photoactivated disks only, indicating efficient photo-immobilization of the applied peptide. The quantity of amino acid released with each Edman-degradation cycle conferred with the established philicity of amino-acid side chains for photogenerated carbenes. The procedure provides a hitherto unexplored way to immobilize biomolecules (polypeptides) through statistically occurring carbene or nitrene insertions.

\section{Introduction}

Adsorption or covalent immobilization of polypeptides to solid supports are crucial steps in bio-analytical procedures including electrophoretic transfer of proteins from polyacrylamide gels to solid supports by electroblotting and immobilization of polypeptides for solid-phase and gas-phase sequence analysis. The efficiency of the methods mentioned depends on the protein-bin- ding capacity of the supporting material. To date, chemically inert supports are either pretreated or modified by various means to achieve improved polypeptide retention. For sequencing purposes, glass fibers are coated with polybrene, a quaternary ammonium polybase, or modified with positively of ionic forces to retain the adsorbed protein [1][2]. Covalently modified glass fibers, derived with bifunctional reagents, provide charged silanes. Both procedures make use means for group-specific protein binding [3][4]. Hydrophobic and electrostatic forces are involved in polypeptide retention on siliconized glass fiber [5] and polyvinylidenedifluoride (PVDF) membranes [6].

This study reports on the preparation and characterization of photoactivable supports, which carry monomolecular layers of carbene- or nitrene-generating photoreagents. Photo-activation of photolabel-derived supports in the presence of a hexapeptide leads to covalent polypeptide immobilization by carbene/nitrene insertion. Evidence is presented that photocoupled peptides can be sequenced by $E d m a n$-degradation-based gasphase microsequencing.

\section{Experimental}

Photoactivable Glass Fibers: Preparation and Loading

The bifunctional photoreagents 3-(trifluoromethyl)3-[m-(isothiocyano)phenyl]diazirine (TRIMID) and $p$ azidophenyl isothiocyanate (API) were synthesized as described in [7][8]. GF/C glass fiber sheets (Whatmam) were aminopropylated according to Aebersold et al. [2] yielding 14 nmol of $\mathrm{NH}$ groups per mg glass fiber. Dried aminopropylated glass-fiber sheets were cut into dises of $1.2 \mathrm{~cm}$ in diameter.

\footnotetext{
*Correspondence: PD Dr. Hans Sigrist

1) Institut für Biochemie

Universität Bern

Freiestrasse 3, CH-3012 Bern

2) Niedersächsisches Institut für Peptidforschung im Medical Park

Feodor-Lynen-Strasse 5, D-3000 Hannover 61
} 


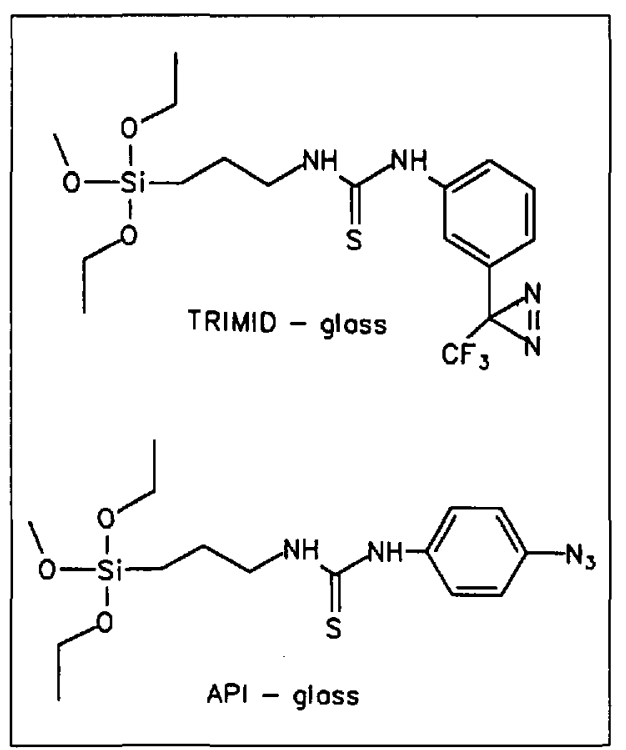

Fig. 1. Structure of aminopropylated glass fibers thiocarbamoylated with 3-(trifluoromethyl)-3-[m-(isothiocyano)-phenyl]diazirine (TRIMID-glass) or p-azidophenylisothiocyanate (API-glass) photoactivated. Released amino acids were identified and spectrophotometrically quantified as phenylthiohydantoin derivatives

\section{Results}

Philicity of Amino-Acid Side Chains for Photogenerated Nitrenes and Carbenes

Amino-acid binding capacities of carbene- and nitrene-generating supports (Fig. l) were investigated by analyzing net amino-acid retention upon photocoupling of radioactive tyrosine or alanine. ${ }^{14} \mathrm{C}$-tyrosine $(166 \mathrm{pmol})$ or ${ }^{14} \mathrm{C}$-alanine $(110 \mathrm{pmol})$ were added per mg photoactivable support of either system: Analysis of net radiolabel binding revealed that photogenerated nitrene supports bind $8.2 \%$ of applied tyrosine and $1.2 \%$ of applied alanine. Amino-acid binding to photogenerated carbene supports was in line with previously reported results [10] (3.6\% of applied tyrosine and $2.2 \%$ of applied alanine). Since the conditions for photoactivation of TRIMID-glass and API-glass differ significantly in light intensity, dura- tion, and the spectrum of activating light, it is at present not possible to comparatively qualify the two supports. However, the results clearly document that both types of photoactivable glass fiber are capable of establishing covalent links with amino acids. The newly described photo-activable supports are thus applicable for polypeptide coupling.

\section{Gas-Phase Sequence Analysis of a Photo- coupled Hexapeptide}

The hexapeptide H-Leu-Trp-Met-ArgPhe-Ala-OH (10 nmol per disc) was spotted to each of the supports and photo-activated as described in Experimental. Subsequent sequencing of washed discs indicated that the polypeptide was retained on photoactivated discs only, initial yields being $10.9 \%$ for the carbene-coupled peptide and $5.7 \%$ for the hexapeptide immobilized via photogenerated nitrenes (Fig. 2). The results further showed that end-to-end sequencing of photo-immobilized peptides is feasible and suggest that carbene- and nitrene-insertion re-
Preparation of TRIMID Glass

A minopropylated glass-fiber discs were incubated with TRIMID dissolved in $\mathrm{CHCl}_{3} / \mathrm{Et}_{3} \mathrm{~N}$ 200:0.1 $(\mathrm{v} / \mathrm{v})$ with a 10-fold molar excess of photolabel over available $\mathrm{NH}_{2}$ groups. Thiocarbamoylation of the supports was carried out for $20 \mathrm{~min}$ at $50^{\circ}$ on a labshaker. Photolabel-derivatized glass fibers were washed with $\mathrm{CHCl}_{3}(16 \mathrm{ml})$ followed by $4 \mathrm{~mm}$ cysteine, $\mathrm{pH} 7.4(4 \mathrm{ml})$ and $\mathrm{CHCl}_{3}(6 \mathrm{ml})$.

\section{Preparation of APl-Glass}

Aminopropylated glass-fiber discs were incubated in $17 \mathrm{mM} \mathrm{API}$ in cyclohexane for $90 \mathrm{~min}$ at $40^{\circ}$. Modified discs were washed with $90 \mathrm{ml}$ of $\mathrm{CHCl}_{3}$, dried with $\mathrm{N}$, and stored at $-20^{\circ}[9]$.

The protein-(amino-acid)binding capacity of photolabel-derivatized discs was determined by analyzing light-dependent immobilization of $\mathrm{L}-\left(\mathrm{U}-{ }^{14} \mathrm{C}\right)$-tyrosine (Amersham, $8.33 \mathrm{GBq}^{\mathrm{mmol}}{ }^{-1}$ ) and $\mathrm{L}-\left(\mathrm{U}-{ }^{14} \mathrm{C}\right)$ alanine (Amersham, $2.78 \mathrm{GBq} \mathrm{mmol}^{1}$ ), resp. The hexapeptide H-Leu-Trp-Met-Arg-Phe-Ala-OH (Serva) dissolved in $15 \mu \mathrm{l}$ of $\mathrm{H}_{2} \mathrm{O}$ was spotted to wet (5 $\mu \mathrm{EtOH}$ ) photoactivable glass-fiber discs. Before photoactivation, applied substances were dried under $\mathrm{N}_{2}$.

\section{Photoactivation}

TRIMID-derivatized glass-fiber discs were placed between two quartz slides in a custom-made holder. The holder was positioned $45 \mathrm{~cm}$ from the light source (HBO $350 \mathrm{Hg}$ lamp, Osram). Samples were photoactivated (controlled lamp power $200 \mathrm{~W}$ ) under $\mathrm{Ar}$ with filtered light (Schott $W G 320$ and a $1 \mathrm{~cm}$ layer of sat. CuSO in $\mathrm{H} \mathrm{O}$; transmission band width $320-550 \mathrm{~nm}$ ) for $16^{4} \mathrm{~min}^{2}(8 \mathrm{~min}$ each filter face). API-derivatized glass-fiber discs were photoactivated with consecutive flashes from an electronic flash unit of a camera $(O p$ tatron 350, Loewe Opta) with the protecting screen removed. Samples were placed $4 \mathrm{~cm}$ apart from the light source and exposed with 40 flashes ( 20 for each disc face). Photoactivated glass-fiber discs were thoroughly washed with solvents, applied in the following sequence and quantities: $1 \mathrm{M} \mathrm{NaCl}(20 \mathrm{ml}), \mathrm{H}_{2} \mathrm{O}(10 \mathrm{ml})$, $\mathrm{EtOH}(10 \mathrm{ml}), \mathrm{CHCl}_{3}(10 \mathrm{ml})$, toluene $(10 \mathrm{ml})$

\section{Sequence Analysis}

$N$-Terminal sequence analysis of the photocoupled hexapeptide was carried out using an Applied Biosystem. 477A Protein Sequencer. Extensively washed fiber discs were sequenced without addition of polybrene. Control samples were identically treated but not
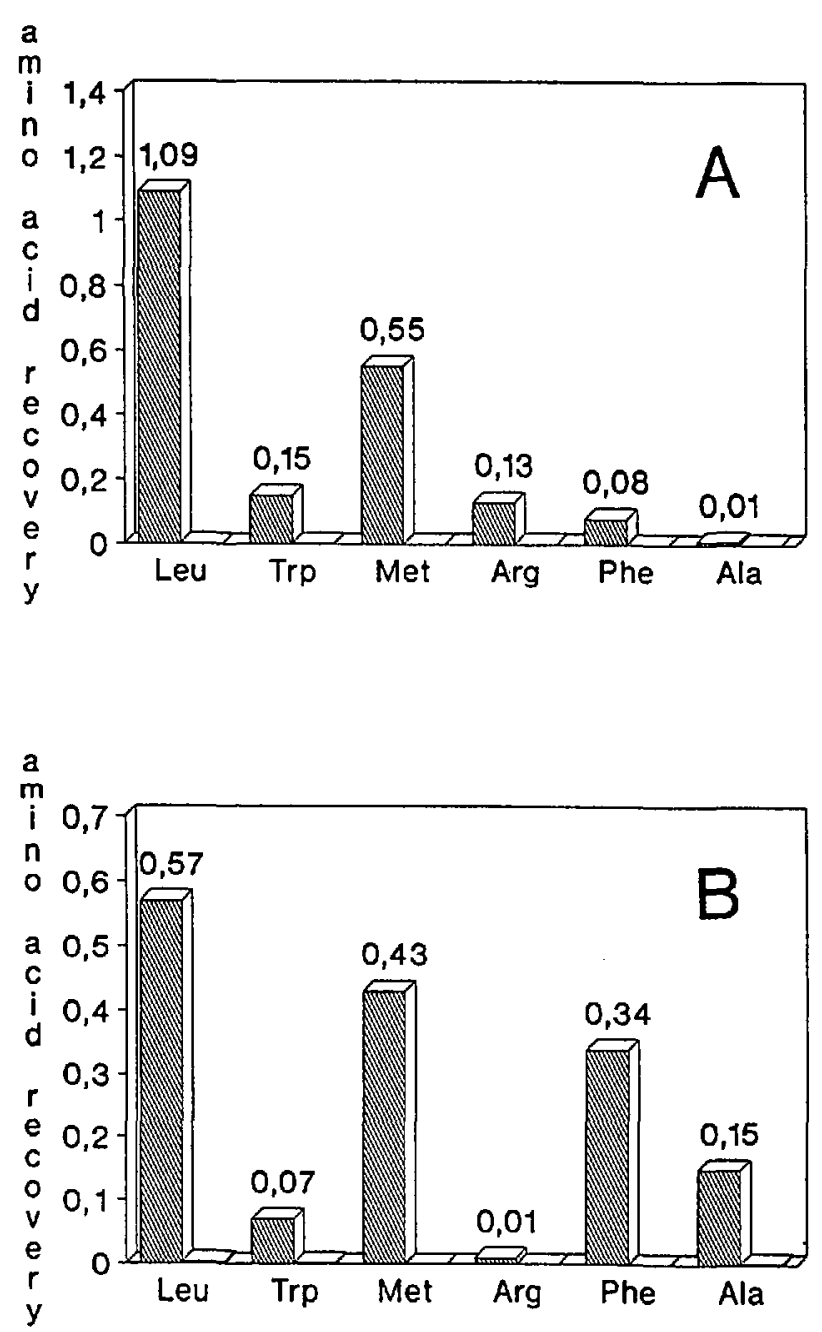

Fig. 2. The hexapeptide H-Leu-Trp-Met-Arg-Phe-Ala-OH (10 nmol, $15 \mu 1)$ was spotted to TRIMID-glass $(A)$ or API-glass $(B)$. Impregnated supports were photoactivated, thoroughly washed and submitted to automated sequence analysis. Amino-acid recoveries (nmol) are depicted for photoactivated (N) and control samples without photoactivation 
actions occur with all constituting aminoacid side chains (Fig. 2). That the recovery of tryptophan in the second Edman-degradation step is lower than the following methionine (Fig. $2 \mathrm{~A}$ ) is in accordance with the observed high carbene philicity of tryptophan [10]. An apparent limitation of the newly described immobilization system is the low recovery of applied peptide due to the limiting number of available photoactive functions. Experiments designed to augment photolabel density are in progress.

\section{Discussion}

Gas-phase sequencing procedures currently applied in protein chemical analysis are based mainly on noncovalent interactions between the polypeptide (to be sequenced) and an adsorbing solid support (impregnated glass, PVDF membranes). Alternatively, classical solid-phase sequencing techniques utilize covalent group-specific reactions for chemical polypeptide immobili- zation [3]. In either case, proteins are spotted or blotted onto supporting discs or membrane material. Due to side reactions with buffer components, efficient blotting of polypeptides to functionalized membranes is difficult. Furthermore, removal of blotting buffer or detergents before sequence analysis may lead to uncontrolled polypeptide loss. The described photo-activable supports provide a new and attractive way to immobilize polypeptides (and biomolecules in general) by nonspecific random covalent interactions [11]. Immobilized photoreagents serve as molecular glue. Photolabel-derivatized supports are 'chemically inert' until light exposure. With reference to the diazirine-derivatized (TRIMID) glass, the activating light $(350 \mathrm{~nm})$ is not destructive for protein structure and function [12].

This research was supported by $E M B O$ (fellowship to $V, K,-D$.), the Sandoz Foundation, and the Swiss National Science Foundation (grants No. 3.391-0.86 and $31-26234.89$ ).

[1] J. Vanderkerchove, G. Braun, M. Puybe, J.van Damme, M. van Montagu, Eur.J. Biochem. 1985 , $152,9$.

[2] R. H. Aebersold, D. B. Teplow, L. E. Hood, S. B. Kent, J. Biol. Chem. 1986, 261, 4229.

[3] W. Machleidt, U. Borchart, A. Ritonja, in 'Advanced Methods in Protein Microsequence Antalysis', Eds. B. Wittmann-Licbold, J. Salnikov, and V. A. Erdmann, Springer Verlag, Berlin. 1986, p. 91.

[4] R. H. Aebersold, G. D. Pipes, H. Nika, L. E. Hood, S. B. Kent, Biochemist y 1988, 27,6860.

[5] C. Eckerskorn, W. Mewes, H. Goretzki, F. Lottspeich, Eur. J. Biochem. 1988, 176, 509.

[6] P. Madsudaira, J. Biol. Chem. 1987, 262, 10035.

[7] H. Sigrist, P. R. Allegrini, C. Kempf, C. Schnippering, P.Zahler, Eur.J.Binchem. 1982, 125, 197.

[8] M. Dolder, H. Michel. H. Sigrist, J. Prot. Chem. $1990,9,407$.

[9] API-glass fibers were not washed with aqueous cysteine due to thiol interference with the azide function as described by E. F. V. Scriven, K. Tumbell, Chem. Rev. 1988, 88, 326.

[10] H.Sigrist, M. Mühlemann, M. Dolder. J. Photochem. Photobiol., B 1990, 7, 277.

[11] H. Sigrist, V.Klingler-Dabral, W-G. Forssmann, M. Dolder, Patent applied, 1990.

[12] J. Brunner, Meth. Enzymol. 1989, 172, 628.

Chimia 45 (1991) 45-49

(c) Schweiz. Chemiker-Verband; ISSN 0009-4293

\section{Inhibition of the Nicotinic Ion Channel by Arachidonic Acid and Other Unsaturated Fatty Acids in Chromaffin Cells from Bovine Adrenal Medulla**}

\author{
Markus U. Ehrengruber and Peter Zahler*
}

\begin{abstract}
The effects of arachidonic and other cis-unsaturated fatty acids were investigated in cultured chromaffin cells from bovine adrenal medulla with respect to $\mathrm{Ca}^{2+}$ influx and secretion of catecholamines. As previously shown, arachidonic acid generated during the signal transduction is essential for the fusion of the chromaffin granules with the plasma membrane and by this enables secretion [10-12]. However, if one adds arachidonic acid externally before the agonist, this leads to a partial inhibition of the cholinergic induced secretion. Preincubation with cis-unsaturated fatty acids totally blocks the cholinergic induced $\mathrm{Ca}^{2+}$ influx but not the $\mathrm{Ca}^{2+}$ influx evoked by the voltage gated $\mathrm{Ca}^{2+}$ channel. This inhibition is not due to activation of protein kinase $\mathrm{Cby}$ arachidonic acid, since preincubation with PMA does not block the receptor-dependent $\mathrm{Ca}^{2+}$ influx. Preincubation with 5-, 12 , 15-HETE and 12-HPETE does not inhibit the receptor-dependent $\mathrm{Ca}^{2+}$ influx, indicating that eicosanoids are not responsible for the inhibition. This statement is supported by the fact that BW755C does not reverse the arachidonic acid-evoked blockade of the receptordependent $\mathrm{Ca}^{2+}$ influx. These results demonstrate that cis-unsaturated fatty acids and especially arachidonic acid inhibit the receptor-dependent $\mathrm{Ca}^{2+}$ influx by blocking the nicotinic cation channel. The generation of arachidonic acid in the physiological process of the stimulus-response coupling may, thus, contribute to the relaxation, of the cell by preventing further $\mathrm{Ca}^{2+}$ influx.
\end{abstract}

\section{Introduction}

Chromaffin cells (CC) from adrenal medulla secrete catecholamines upon stimulation by cholinergic agonists, $e$.g. acetylcholine (ACh) or by depolarization of the plasma mebrane with high $\mathrm{K}^{+}[1]$. Stimulation of the cells leads to membrane depolarization and causes a transient increase of membrane permeability to $\mathrm{Ca}^{2+}\left(\mathrm{Ca}^{2+}\right.$ influx $)$ which is necessary for the initiation of the secretion [2]. The cells contain nicotinic and muscarinic receptors, both of them beeing activated by ACh [3]. Muscarinic receptors exhibit a higher affinity for ACh [4] and activate the phosphatidylinositol cycle in bovine adrenal medulla without inducing catecholamine secretion [5]. The nicotinic receptor is a heteropentameric complex containing the ligand-binding structure and a cation-selective channel [6]. The supposed physiological sequence of events leading to the large transient increase in cytosolic free calcium concentration $\left(\left[\mathrm{Ca}^{2+}\right]_{i}\right)$ is initiated, when $\mathrm{ACh}$ binds to the nicotinic receptor and

\section{*Correspondence: Prof. Dr. P. Zahler \\ Institut für Biochemie \\ Universität Bern \\ Freiestr. 3, CH-3012 Bern}

**Abbrevations used: AA: arachidonic acid; $\mathrm{ACh}$ acetylcholine; BW755C: 3-amino-1-13-(trifluoromethyl)phenyl]-2-pyrazoline; $\left[\mathrm{Ca}^{2+}\right]_{i}$ : cytosolic free calcium concentration; $\mathrm{CC}$ : chromatfin cells: HETE: hydroxyicosatetraenoic acid; HPETE: hydroperoxyicosaterraenoic acid; PKC: protein kinase C; PMA: phorbol-12-myristate-13-acetate; UFA: unsaturated fatty acid. 